\title{
Markers of acute-phase response in the treatment of pulmonary tuberculosis
}

\author{
Marcadores de resposta de fase aguda no tratamento da tuberculose pulmonar
}

Cristiane Martins ${ }^{1}$; Antônio Carlos de Castro Gama²; Daniela Valcarenghi³; Anna Paula de Borba Batschauer ${ }^{4}$

\begin{abstract}
Introduction: Tuberculosis promotes an acute phase response with an increase of blood reactants, such as C-reactive protein (CRP), among others, which are associated with increased erythrocyte sedimentation rate (ESR). Objective: Evaluate the ESR and the CRP as markers for diagnosis and monitoring cases of pulmonary tuberculosis. Method: Research on patients with clinical, laboratory, and imaging diagnosis of pulmonary tuberculosis, from Itajaí-SC; in which CRP and ESR were analyzed in three different times: at diagnosis, before starting treatment (T0), after three months of treatment (T1), and at the end of treatment (T2). Results: 51 patients were studied at T0 (100\%), $43(84.31 \%)$ at T1, and $32(62.74 \%)$ at T2. ESR and CRP values presented significant differences in the three different times $(p<0.0001 * * *)$. When analyzing the relationship between negative/positive sputum and altered/normal ESR and CRP at T0, ESR $(\phi=0.0691)$, CRP $(p=0.0166 *)$. For chest imaging and sputum smear variables it was observed the following: CRP versus smear $(p$ $\left.=0.0002^{* * *}\right)$, ESR versus smear $(\phi=0.3810)$, CRP versus chest imaging $\left(\phi=0.0097^{* *}\right)$, and ESR versus chest imaging $(\phi=0.0766)$. The correlation between ESR and CRP was: T0 $\left(p=0.0033^{* *}\right), \mathrm{T} 1\left(p<0.0001^{* * *}\right)$ and T2 $\left(p=0.0015^{* *}\right)$. Conclusion: ESR and CRP proved to be good markers in the diagnosis and monitoring of tuberculosis cases, however, CRP achieve more significant results than ESR.
\end{abstract}

Key words: pulmonary tuberculosis; C-reactive protein; erythrocyte sedimentation rate.

\section{INTRODUCTION}

Tuberculosis is an infectious disease caused by Mycobacterium tuberculosis, which mainly affects the lungs, where the lesions are caused by host response due to protective immunity and pathological hypersensitivity. The tissue-resident macrophages of lung constitute first line of defense against the mycobacteria, and together with helper T lymphocytes (CD4+) that play the main role in the immune response to mycobacteria producing cytokines, such as interferon-gamma (IFN- $\gamma$ ), that activate macrophages and enhances the ability to destroy the phagocytosed bacilli ${ }^{(13,23,25)}$.

In the immune response, the cytokines produced participate in the regulatory processes, as well as in effector functions, and are involved in the activation and proliferation of macrophages and $\mathrm{T}$ lymphocytes. Thus, specific antigens of the mycobacteria interact with toll-like receptors (TLRs) and other receptors present on the surface of macrophages and dendritic cells, thus inducing a cellular immune response predominantly proinflammatory ${ }^{(13,15)}$.

The inflammatory reaction is accompanied by a systemic response known as acute-phase response (APR). This response is characterized by fever, production of different types of hormones, leukocytosis, and protein synthesis in series, which is rapidly regulated, mainly in the hepatocytes, under the control of cytokines arising from the site of the pathology ${ }^{(9,}$ ${ }^{26}$. Among the APR proteins, the C-reactive protein (CRP) stands out, since its serum level is increased about a thousand times during acute inflammation. This protein binds to a variety of pathogens and activates the proteins from complement system,

First submission on 11/08/14; last submission on 27/11/14; accepted for publication on 29/11/14; published on 20/12/14

1. Biomedicine student; nursing technician at the Tuberculosis Programme of the Municipal Health Department of Itajaí.

2. Pulmonologist at the Tuberculosis Programme of the Municipal Health Department of Itajaí.

3. MSc in Pharmaceutical Sciences by Vale do Itajaí University (Univali); teaching the disciplines of Clinical Bacteriology and Microbiology of Pharmacy and Biomedical Sciences at Univali.

4. Phd in Clinical and Toxicological Analysos by Minas Gerais Federal University (UFMG); teaching the discipline of Hematology of Pharmacy and Biomedical Sciences at Univali. 
enabling phagocytosis of pathogens. CRP production is part of the nonspecific acute-phase response of most inflammation, infection, and tissue damage ${ }^{(1,16)}$.

The erythrocyte sedimentation rate test (ESR) measures, in millimeters, the sedimentation of erythrocytes in a standard column after a period of 60 minutes ${ }^{(24)}$, where red blood cells are neutralized by plasma proteins such as fibrinogen, allowing their stacking aggregation, rather than individually. Thus, during the APR, the increased serum proteins promotes an increase in the $\mathrm{ESR}^{(17,21)}$.

Regardless the triggering event, during the APR hepatic synthesis increases and, therefore, serum levels of acute-phase proteins, such as CRP and fibrinogen, among others, also increase in proportion to the intensity of damage and tissue destruction ${ }^{(21)}$.

Thus, the study aimed to analyze the APR markers at different times of the disease, which were applied to patients of a reference center for infectious and contagious diseases in order to assess the ESR and the CRP as a marker for diagnosis and monitoring of pulmonary tuberculosis cases.

\section{METHOD}

In a prospective cohort study, we initially selected 79 patients with pulmonary tuberculosis at the Tuberculosis Control Program in the city of Itajaí-SC. Of these, 12 were reported with admission by transference, seven were internees from the prison and penitentiary of the city, and nine were not located for the first blood collection, totaling 28 patients excluded from the study. Data analyzes and blood collections were carried out in the period from September 13, 2012 to December 17, 2013; the inclusion criterion was the diagnosis of pulmonary tuberculosis performed by clinical laboratory data, in sputum smear microscopy and/or sputum culture, carried out by Ziehl-Neelsen and Löwenstein_Jensen (LJ) methods, respectively, associated with chest image (CI), X-ray test and/or CT scan, besides not having yet started anti-TB treatment for the first blood collection of the study. The positive sputum smear were quantified by the number of resuistant acid-alcohol-fast bacilli in the sample $(+$, $++,+++)$, as recommended by the Ministry of Health ${ }^{(2)}$, and the chest images analyzed regarding severity: diffuse disease, cavitations, and other alterations. Patients also underwent complementary laboratory tests to tuberculosis treatment, such as serologic test for human immunodeficiency virus (HIV) and viral hepatitis panel, complete blood count, blood glucose, and acute phase markers (CRP and ESR).
The material (whole blood and serum) for ESR and CRP analysis was collected during the Tuberculosis Program at three different times: at diagnosis, before the start of treatment (T0), after three months of treatment (T1), and at the end of treatment (T2). The ESR test was carried out by the Westergren method, in which a volume of $200 \mathrm{~mm}$ of whole blood collected in ethylenediaminetetraacetic acid (EDTA) was aspirated into Westergren pipette, and placed vertically in the rack over a period of 1 hour, with reference value: $\operatorname{man} \leq 15 \mathrm{~mm}$ and woman $\leq 20 \mathrm{~mm}^{(27)}$. The CRP test was performed with Latex Immunoassay kit using latex particles coated with anti-CRP monoclonal antibodies by indirect agglutination with reference value $\leq 6 \mathrm{mg} / \mathrm{l}^{(4)}$.

The project was approved by the Research Ethics Committee of Vale do Itajaí University, under number 115.172/12. Clinical and laboratory data were obtained from patient's records in a secure and confidential manner, and subsequently were transferred to a database; the variables were analyzed using Fisher's test, analysis of variance (ANOVA), and the study of Pearson's correlation, using the GraphPad Prism 5.0 software.

\section{RESULTS}

From the 79 patients selected, 51 were included in the study, 16 female, with a median of 36 years of age, and 35 male, with a median of 40 years of age. During the study, eight (15.69\%) patients were discharged for abandonment of treatment, two (3.92\%) were transferred to another city, one (1.96\%) died, and eight (15.69\%) did not attend the last appointment, resulting in a reduced number of samples at $\mathrm{T} 1$ and $\mathrm{T} 2$, for a total of $51(100 \%)$ patients to collection at T0, $43(84.31 \%)$ at T1, and $32(62.74 \%)$ at T2. Sputum smear microscopy was performed for all patients at diagnosis, with $84.31 \%$ positive; of these, $76.74 \%$ were smear control at T1, of which, $81.81 \%$ resulted negative. Clinical and laboratory characteristics of patients are shown in Table 1.

0 ESR at T0 was altered in 45 (88.24\%) examinations, and normal in six (11.76\%); at T1, 19 (44.19\%) results were still altered and 24 (55.81\%) were normal; at T2, eight (25.00\%) were altered, and 24 (75.00\%) were normal. CRP presented at T0 45 (88.24\%) altered tests, and six (11.76\%) normal results; at T1, 14 (32.56\%) results were still altered and $29(67.44 \%)$ were normal; at T2, only five (15.63\%) were altered, and 27 (84.37\%) were normal. For the two markers, gradual decrease was observed during treatment progression. The results of the tests from ESR and CRP are shown in Figures 1A and 1B. 
TABLE 1 - Clinical and laboratorial characterization of 51 patients of the study at $\mathrm{T} 0$

\begin{tabular}{|c|c|c|}
\hline \multirow{2}{*}{ Characteristic } & \multicolumn{2}{|c|}{ Patients } \\
\hline & $n$ & $\%$ \\
\hline \multicolumn{3}{|l|}{ Sex } \\
\hline Male & 35 & 68.62 \\
\hline Female & 16 & 31.37 \\
\hline \multicolumn{3}{|l|}{ Comorbidities } \\
\hline Smoking & 27 & 52.94 \\
\hline Alcoholism & 10 & 19.61 \\
\hline Drug abuse & 11 & 21.57 \\
\hline Type II diabetes & 6 & 11.76 \\
\hline Seropositive for HIV & 2 & 3.92 \\
\hline \multicolumn{3}{|l|}{ Anemia } \\
\hline Normocytic/normochromic & 25 & 64.10 \\
\hline Microcytic/hipochromic & 13 & 33.33 \\
\hline Macrocytic/normochromic & 1 & 2.57 \\
\hline \multicolumn{3}{|l|}{ Chest image examination } \\
\hline Diffuse disease & 6 & 11.76 \\
\hline Cavitation & 36 & 70.58 \\
\hline Other alterations & 9 & 17.64 \\
\hline \multicolumn{3}{|l|}{ Sputum smear microscopy } \\
\hline Positive (+) & 14 & 27.45 \\
\hline Positive $(++)$ & 18 & 35.29 \\
\hline Positive $(+++)$ & 11 & 21.57 \\
\hline Negative & 8 & 15.69 \\
\hline \multicolumn{3}{|l|}{ Sputum culture } \\
\hline Positive & 34 & 91.89 \\
\hline Negative & 3 & 8.10 \\
\hline Not performed & 14 & 27.45 \\
\hline
\end{tabular}

TO: time of diagnosis, before starting treatment; HIV: human immunodeficiency virus.

\section{DISCUSSION}

This study, among patients with pulmonary tuberculosis were identified several associated comorbidities, such as smoking, alcohol consumption, drug abuse, diabetes mellitus (DM), HIV seropositivity and anemia (Table 1). These comorbidities are strongly related to tuberculosis, as shown by several studies: smoking is present in more than half of the patients ${ }^{(11,19)}$, DM showed an index of $13.2 \%{ }^{(12)}$, and HIV, $4.6 \%{ }^{(18)}$. All these references had similar results to our study's findings. The rate of alcohol users was low in this study when compared to Lima et $a l^{(11)}$, and drug abuse was higher than Ribeiro et al. findings ${ }^{(19)}$. Anemia was a frequent finding in the studied patients (86.67\%), showing
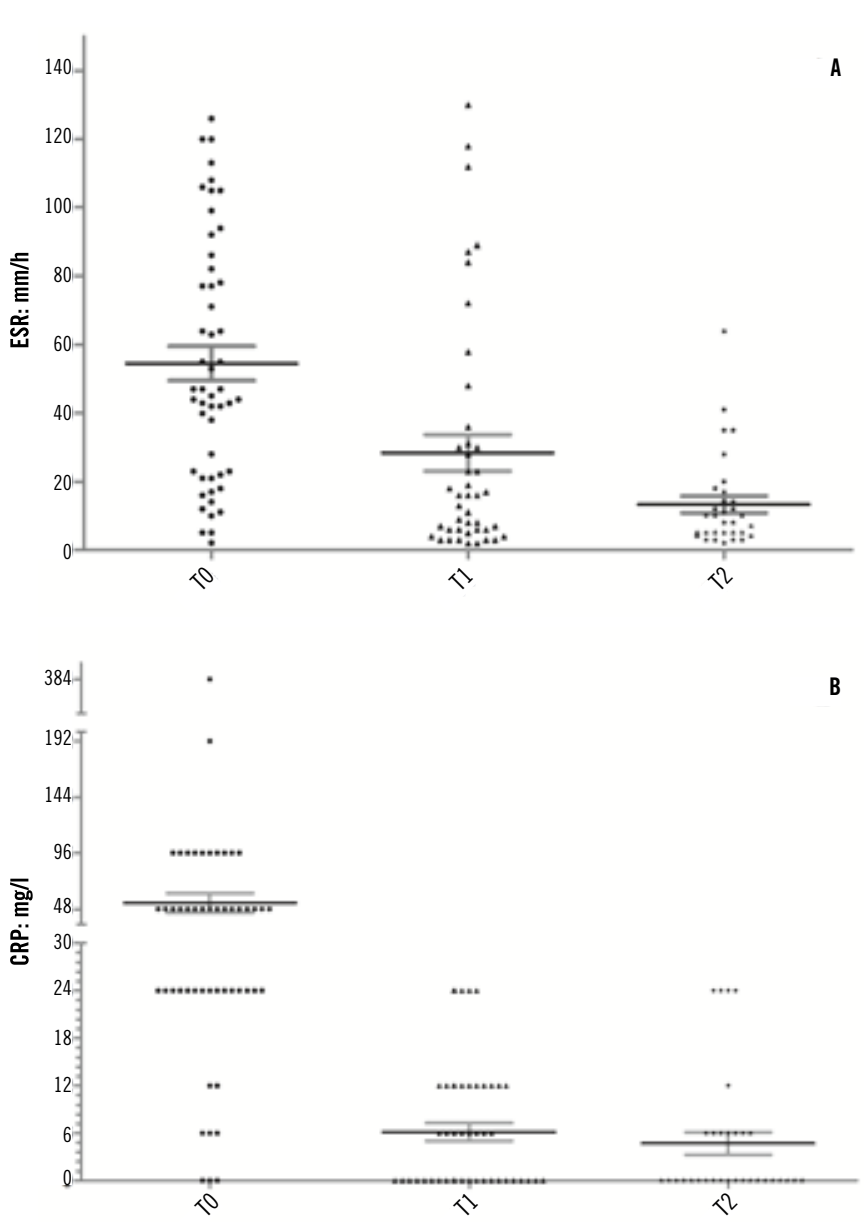

FIGURE 1 - Column graphs using ANOVA test, showing the relation between ESR and CRP at TO, T1, and T2

Test significance for $* \mathrm{p}<0.05 ;{ }^{* *} \mathrm{p}<0.005 ;{ }^{* * *} \mathrm{p}<0.0005$.

A) $\mathrm{p}<0.0001^{* * *}$; B) $\mathrm{p}<0.0001^{* * *}$.

ANOVA: analysis of variance; ESR: erythrocyte sedimentation rate; CRP: C-reactive protein; T0: time of diagnosis, before starting treatment; T1: after three months of treatment; T2: at the end of treatment.

the relationship between chronic disease and the occurrence of normocytic normochromic anemia (64.10\%), however, diverging results are found in the literature ${ }^{(7,10)}$.

Signs of activity were detected in all CI diagnostic tests analyzed, cavitations was the most frequent (70.58\%) finding in the study. Similar results were emphasized in another study, with $67 \%$ of images with cavitations ${ }^{(3)}$. However, in two other studies, $53.1 \%$ and $36.7 \%$ of chest image with cavitations were found $^{(11,14)}$, results discordant to that found. It is suggested that the highest percentage of cavitations in the present study is related to diagnostic delay, since more than half of the patients presented respiratory symptoms for more than two months. 
Sputum smear microscopy was performed for all patients at diagnosis with high positivity, and negativity at $\mathrm{T} 1$ in most cases. The culture was positive in a larger number of cases at $\mathrm{T} 0$, showing to be more sensitive than smear microscopy. Lima et al ${ }^{(11)}$ found a rate of $58.4 \%$ positivity in the smear with $67.6 \%$ in the culture. Another study obtained $55.3 \%$ positivity in the sputum smear microscopy ${ }^{(5)}$, these results are divergent from that found in the present study, which identified a greater sensitivity in both smear and in culture at diagnosis.

In the ESR and CRP analysis, these markers were above the reference value before the start of anti TB treatment, with a gradual decrease over the course of treatment, with $p<0.0001$ (Figure 1), showing to be good markers in diagnosis and monitoring of cases. Sahiratmadja et al.$^{(20)}$ obtained results similar to ours in the present study, with an increase of ESR and CRP levels before initiation of treatment, and decrease of ESR and normalization of CRP at the end of treatment. Divergent results were reported in another study ${ }^{(17)}$, in which, only the CRP showed to be a good marker in clinical practice to evaluate the response to the treatment. Regarding diagnosis, both the CRP and ESR proved to be good markers.

By analyzing the results of smear microscopy and sputum culture at T1 (Table 2), it can be observed that the ESR and CRP were significantly associated with bacterial conversion. Similar results were reported in another study with $\mathrm{CRP}^{(14)}$, but the same was not observed for ESR marker. When CI variable and the smear were evaluated, CRP also showed a significant association (Table 3), as shown in published reports ${ }^{(6,22)}$, in which CRP levels were significantly higher in the most severe tuberculosis before starting treatment.

In assessing the correlation between ESR and CRP, it can be observed a moderate correlation between the two markers (Figure 2), which corroborates the findings of another study ${ }^{(6)}$, in which there was a moderate correlation between ESR and CRP.

TABLE 2 - Comparison of positive/negative sputum $p$-value versus altered/normal ESR and CRP at T0 and T1, by Fisher's method

\begin{tabular}{ccc}
\hline \multicolumn{3}{c}{ Sputum } \\
\hline ESR & T0 & T1 \\
CRP & 0.0691 & $0.0045^{* *}$ \\
& $0.0166^{*}$ & $0.0123^{*}$ \\
\hline
\end{tabular}

Test significance for $* \mathrm{p}<0.05 ;{ }^{* *} \mathrm{p}<0.005 ;{ }^{* * * *} \mathrm{P}<0,0005$.

Sputum: smear and/or culture positive/negative; ESR: erythrocyte sedimentation rate; CRP: C-reactive protein; T0: time of diagnosis, before starting treatment; T1: after three months of treatment.
TABLE 3 - Comparison of $p$-value between CRP, ESR versus the severity of $\mathrm{CI}$ and smear at $\mathrm{T} 0$, by non-parametric ANOVA method

\begin{tabular}{ccc}
\hline & IT & Smear \\
\hline CRP & $0.0097^{* * *}$ & $0.0002^{* * *}$ \\
ESR & 0.0766 & 0.3810 \\
CI & - & $0.0304^{*}$ \\
\hline
\end{tabular}

Test significance for * $\mathrm{p}<0.05 ; * * \mathrm{p}<0.005 ; * * * \mathrm{p}<0.0005$.

CRP: C-reactive protein; ESR: erythrocyte sedimentation rate; CI: chest image; T0: time of diagnosis, before starting treatment; ANOVA: analysis of variance.

In contrast, Jeremiah et al ${ }^{(8)}$ found no correlation between ESR and CRP in the early diagnosis of tuberculosis, describing that the CRP can not be used as a screening tool for the early diagnosis of tuberculosis.

We concluded that the ESR and CRP proved to be good markers for diagnosis and monitoring of pulmonary tuberculosis treatment; they can be used in routine clinical practice of these patients, however CRP showed more significant results than ESR. It is important to mention that these tests are not specific for tuberculosis, thus it is required the combined use of other parameters, such as clinical, radiological, and conventional microbiological data. Together these parameters become an indispensable tool in the diagnosis and monitoring of these patients.
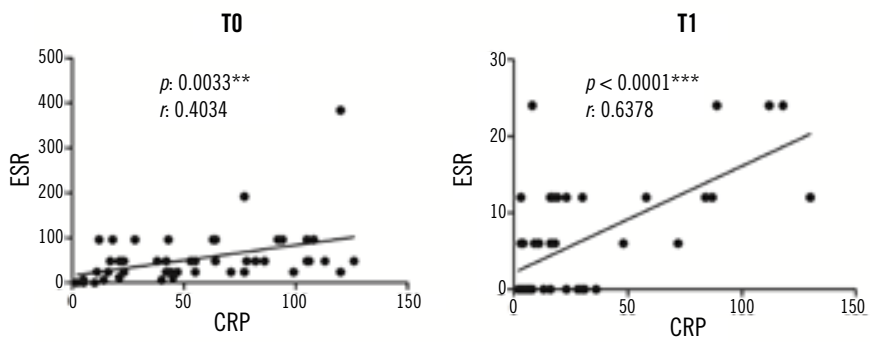

T2

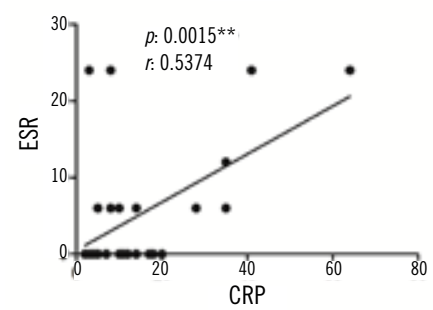

FIGURE 2 - Pearson's correlation plot comparing $\mathrm{p}$ and $\mathrm{r}$ values between ESR and CRP at TO, T1, and T2

Test significance for $* \mathrm{p}<0.05 ; * * \mathrm{p}<0.005 ; * * * \mathrm{p}<0.0005$.

ESR: erythrocyte sedimentation rate; CRP: C-reactive protein; T0: time of diagnosis, before starting treatment; T1: after three months of treatment; T2: at the end of treatment. 


\section{RESUMO}

Introdução: A tuberculose causa uma resposta de fase aguda com aumento de proteínas sanguíneas, como a proteína C reativa (PCR), entre outras, que estão envolvidas com o aumento da velocidade de hemossedimentação (VHS). Objetivo: Avaliar a VHS e a PCR como marcadores no auxilio diagnóstico e no acompanhamento dos casos de tuberculosepulmonar. Método: Pesquisa realizada com portadores de tuberculose pulmonar com diagnóstico clínico, laboratorial e imaginológico do município de Itajai-SC, nos quais foram analisadas PCR e VHS em três tempos distintos: no momento do diagnóstico, antes do início do tratamento (T0), aos três meses de tratamento (T1) e ao término do tratamento (T2). Resultados: Foram estudados 51 pacientes em T0 (100\%), 43 (84,31\%) em T1 e 32 (62,74\%) em T2. Os valores de VHS e PCR tiveram diferenças significativas nos três tempos ( $<<0,0001 * * *)$. Quando analisada as relações entre escarro positivo/negativo e VHS e PCR alterado/normal em TO, VHS ( $\mathrm{p}=0,0691), P C R\left(\mathrm{p}=0,0166^{*}\right)$. Para as variáveis imagem de tórax e baciloscopia, obteve-se: $P C R$ versus baciloscopia $(\mathrm{p}=0,0002 * * *) ; V H S$ versus baciloscopia $(\mathrm{p}=$ 0,3810); PCR versus imagem de tórax ( $\left.\mathrm{p}=0,0097^{* *}\right) ;$ e VHS versus imagem de tórax $(\mathrm{p}=0,0766)$. Correlação entre VHS e PCR: T0 $\left(\mathrm{p}=0,0033^{* *}\right), T 1(\mathrm{p}<0,0001 * * *)$ e T2 $\left(\mathrm{p}=0,0015^{* *}\right)$. Conclusão: A VHS e a PCR mostraram-se bons marcadores no auxilio diagnóstico e no acompanbamento dos casos de tuberculose, entretanto, a PCR mostrou resultados mais significativos que a VHS.

Unitermos: tuberculose pulmonar; proteína C reativa; velocidade de hemossedimentação..

\section{REFERENCES}

1. BILATE, A. M. B. Inflamação, citocinas, proteínas de fase aguda e implicações terapêuticas. Rev Bras Reumatol, v. 8, n. 2, p. 47-51, 2007.

2. BRASIL. Ministério da Saúde. Secretaria de Vigilância em Saúde. Departamento de Vigilância Epidemiológica. Manual nacional de vigilância laboratorial da tuberculose e outras micobactérias. 1. ed. Brasília: Ministério da Saúde, 2008.

3. CAMPOS, C. A. et al. Tuberculose pulmonar: achados na tomografia computadorizada de alta resolução do tórax em pacientes com doença em atividade comprovada bacteriologicamente. J Pneumol, v. 28, n. 1, p. 23-9, 2002.

4. DIAGNÓSTICA, W. Imuno-látex: PCR. Apresenta kit para pesquisa de PCR. 6. ed. 2011. Available at: <http://www.wamadiagnostica.com.br/ bulas/imuno-latex>. Access: 3 december. 2014.

5. FERREIRA, A. A. A. et al. Os fatores associados à tuberculose pulmonar e à baciloscopia: uma contribuição ao diagnóstico nos serviços de saúde pública. Rev Bras Epidemiol, v. 8, n. 2, p. 142-9, 2005.

6. FURUHASHI, K. et al. Inflammatory markers in active pulmonary tuberculosis: association with Th1/Th2 and Tc1/Tc2 balance. Kekkaku, v. 87, n. 1, p. 1-7, 2012.

7. ISANAKA, S. et al. Iron deficiency and anemia predict mortality in patients with tuberculosis. J Nutr, v. 142, n. 2, p. 350-7, 2012.

8. JEREMIAH, Z. A. et al. Discordantly elevated erythrocyte sedimentation rate (ESR) and depressed C-reactive protein (CRP) values in early diagnosis of pulmonary tuberculosis patients in Maiduguri, Nigeria. Open Journal of Blood Diseases, v. 3, n. 2, p. 74-7, 2013.

9. KLUFT, C. et al. Sensitive markers of inflammation make it possible to study the chronic process: the rise of interest in low levels of C-reactive protein. Vascular Pharmacology, v. 39, n. 3, p. 99-104, 2002.

10. LEE, S. W. et al. The Prevalence and evolution of anemia associated with tuberculosis. J Korean Med Sci, v. 21, n. 6, p. 1028-32, 2006.
11. LIMA, S. S. S. et al. Métodos convencionais e moleculares para 0 diagnóstico da tuberculose pulmonar: um estudo comparativo. J Bras Pneumol, v. 34, n. 12, p. 1056-62, 2008.

12. MIRANDA, S. S. Tratamento da tuberculose em situações especiais. Pulmão RJ, v. 21, n. 1, p. 68-71, 2012.

13. MOUTINHO, I. L. D. Tuberculose: aspectos imunológicos na infecção e na doença. Rev Med Minas Gerais, v. 21, n. 1, p. 42-8, 2011.

14. MULLER, B. L. A. et al. Marcadores inflamatórios e imunogenéticos e sua relação com tuberculose pulmonar. J Bras Pneumol, v. 39, n. 6, p. 719-27, 2013.

15. NORTH, R. J.; JUNG, Y. Immunity to tuberculosis. Annual review of immunology, v. 22, p. 599- 623, 2004.

16. PEPYS, M. B.; HIRSCHFIELD, G. M. C-reactive protein: a critical update. J Clin Investigation, v. 111, n. 12, p. 1805-12, 2003.

17. PERESI, E. et al. Citocinas e proteínas de fase aguda do soro como marcadores de regressão da resposta inflamatória ao tratamento da tuberculose pulmonar.J Bras Pneumol, v. 34, n. 11, p. 942-9, 2008.

18. PRADO, T. N. et al. Perfil epidemiológico de pacientes adultos com tuberculose e AIDS no estado do Espírito Santo, Brasil: relacionamento dos bancos de dados de tuberculose e AIDS.J Bras Pneumol, v. 37, n. 1, p. $93-9,2011$.

19. RIBEIRO, S. A. et al. Estudo caso-controle de indicadores de abandono em doentes com tuberculose.J Pneumol, v. 26, n. 6, p. 291-6, 2000.

20. SAHIRATMADJA, E. et al. Dynamic changes in pro- and antiinflammatory cytokine profiles and gamma interferon receptor signaling integrity correlate with tuberculosis disease activity and response to curative treatment. Infect Immun, v. 75, n. 2, p. 820-9, 2007.

21. SANTOS, V. M. et al. Velocidade de sedimentação das hemácias: utilidade e limitações. Rev Ass Med Brasil, v. 46, n. 3, p. 232-6, 2000.

22. SHAMEEM, M. et al. Correlation of serum C-reactive protein with disease severity in tuberculosis patients. Open Journal of Respiratory Diseases, v. 2, n. 4, p. 95-100, 2012. 
23. SILVA, J. R. L.; BOÉCHAT, N. 0 ressurgimento da tuberculose e 0 impacto do estudo da imunopatogenia pulmonar.J Bras Pneumol, v. 30, n. 4, p. 478-84, 2004.

24. SOARES, A. L.; SANTOS, E. A. Velocidade de hemossedimentação: comparação entre 0 método Microtest X (microssedimentação) e 0 método de referência Westergren. Rev Bras Hematol Hemoter, v. 31, n. 1, p. 47-50, 2009.
25. TEIXEIRA, H. C. et al. Diagnóstico imunológico da tuberculose: problemas e estratégias para o sucesso.J Bras Pneumol, v. 33, n. 3, p. 323-34, 2007.

26. VOLP, A. C. P. et al. Capacidade dos biomarcadores inflamatórios em predizer a síndrome metabólica. Arq Bras Endocrinol Metab, v. 52, n. 3, p. 537-49, 2008.

27. WALLACH,J. B. et al. Wallach interpretação de exames laboratoriais. Rio de Janeiro, RJ: Guanabara Koogan, 2013. 